\title{
PETER ERZBERGER AND THE JOURNAL STUDIA BOTANICA HUNGARICA
}

The recent history of the journal Studia botanica hungarica is strongly related to the scientific activity of Peter Erzberger. In the 1990s he has started to study the Hungarian bryoflora, which activity was supported by his perfect knowledge of Hungarian language and his scientific connections with Hungarian colleagues. In the first years, he published contributions to the Hungarian bryoflora, amendments to the distribution of bryophyte taxa in Hungary and reported taxa for the first time in the country. After the Millennium, he systematically visited the Balkan Peninsula in field trips, organized mainly by Beáta Papp to various countries (for the first time to Serbia, then to Montenegro and other countries).

I met Peter for the first time when we spent two weeks in Montenegro in the autumn of 2002. During this time, we visited the surroundings of Lake Shkodra, Lovčen Mts, Njegus, Bar and Cetinje with Beáta Papp and Dániel Pifkó. The same company, together with László Lőkös visited the Golija Mts in 2003 and the Djerdap National Park in 2005. In October 2010, we had again a joint field trip to Albania. Owing to the different methods of floristic research focusing on bryophytes and vascular plants, indeed, we scarcely spent daytimes together. After the field excursions, when preparing plants and drying mosses, it was the time for sharing experience and for good and long talks. These conversations were particularly interesting, since Peter's native language is German, but it was a great pleasure to listen his rich and spectacular Hungarian speech with a number of various idioms and proverbs being always in the right context and situation.

Further cryptogamic collecting trips to the Balkans were organized up to 2012, where upon Peter's interest focused exclusively to the Hungarian bryoflora and to the systematic grid-based mapping of the bryophytes in Hungary.

From 1999 until recently, contributions to the bryoflora of Serbia in 6 papers, to the flora of Montenegro in 4 papers, to the flora of Albania in 2 papers and to the flora of Greece and Croatia in 1-1 papers were published in our journal with Peter as a co-author. Altogether, in these papers more than 8500 records of nearly 800 species were published as new findings or as the results of revisions. By country, ca 3100 records from Serbia, ca 1800 from Hungary, ca 1600 from Montengero, ca 1000 from the Republic of Macedonia and ca 900 from Albania. 
These records were published on 898 pages, which count nearly one third of the full extent of Studia botanica hungarica in average up to 2014.

By the systematic studies in Hungary, Peter Erzberger established a bryofloristical school with a number of students and young researchers (e.g. Kornél Baráth, János Csiky, Andor Kovács, József Nagy, Csaba Németh, Attila Rigó, Péter Szücs). He, together with Csaba Németh, launched bryofloristical courses to widen the knowledge of bryophytes among botanists and other interested colleagues.

The kind, seemingly old man, with the same kind of appearance in the last 20 years became 70 years old this year. On this occasion, his colleagues, friends, and students kindly greet him with this volume of Studia botanica hungarica. We wish him a long and meaningful retirement period and the possibility to visit all 2832 bryofloristical quadrates in Hungary and wish him several exciting and interesting findings and good weather for the field trips.

The editor

\section{Papers of Peter Erzberger published in Studia botanica hungarica}

ERzberger, P. (1998): Distribution of Dicranum viride and Dicranum tauricum in Hungary. Studia bot. hung. 29: 35-47.

PAPP, B., ÓDOR, P., and ERZBerger, P. (1999-2000): Preliminary data about the present Hungarian local populations of rare European bryophytes. - Studia bot. hung. 30-31: 95-111.

Erzberger, P. (2001): Ditrichum crispatissimum (Muell. Hal.) Paris, a new species of the Hungarian bryoflora, and Ditrichum flexicaule (Schleich. ex Schwaegr.) Hampe in Hungary.

- Studia bot. hung. 32: 87-105.

Erzberger, P. (2002): Minor contribution to the bryoflora of the Cserhát Mts (Hungary). - Studia bot. hung. 33: 41-45.

ERzBerger, P. (2002): Funaria muhlenbergii and Funaria pulchella (Funariaceae, Bryophyta) in Hungary. - Studia bot. hung. 33: 47-63.

PAPP, B. and ERzBerger, P. (2003): Data about the actual local populations of bryophyte species protected in Hungary. - Studia bot. hung. 34: 33-42.

ERzBerger, P. and PAPP, B. (2004): Annotated checklist of Hungarian bryophytes. - Studia bot. hung. 35: 91-149.

Papp, B., Erzberger, P. and Sabovljević, M. (2004): Contributions to the bryophyte flora of Kopaonik Mts (Serbia, Serbia-Montenegro). - Studia bot. hung. 35: 67-79.

Erzberger, P. (2005): The bulbilliferous species of Pohlia (Bryaceae, Musci) in Hungary. - Studia bot. hung. 36: 67-75.

PAPP, B. \& ERZBERger, P. (2005): The bryophyte flora of Golija-Studenica Biosphere Reserve and some adjacent sites (SW Serbia, Serbia-Montenegro). - Studia bot. hung. 36: 101-116.

Papp, B., Erzberger, P. and Sabovljević, M. (2006): Contribution to the bryophyte flora of the Djerdap National Park (E Serbia). - Studia bot. hung. 37: 131-144.

PAPp, B. and ERzberger, P. (2007): Contributions to the bryophyte flora of Montenegro. - Studia bot. hung. 38: 79-94. 
PAPP, B. and Erzberger, P. (2007): Contributions to the bryophyte flora of Western Stara Planina Mts (E Serbia). - Studia bot. hung. 38: 95-123.

ERzberger, P. and SchröDer, W. (2008): The genus Schistidium (Grimmiaceae, Musci) in Hungary. - Studia bot. hung. 39: 27-88.

Papp, B., ERzberger, P. and Dragićević, S. (2008): Contributions to the bryophyte flora of the Orjen Mts, Montenegro. - Studia bot. hung. 39: 101-112.

ERzberger, P. (2009): The genera Grimmia and Coscinodon (Grimmiaceae, Musci) in Hungary. - Studia bot. hung. 40: 37-124.

PAPP, B. and ERZBerger, P. (2009): Contributions to the bryophyte flora of southeastern Serbia: Suva Planina Mts and its surroundings. - Studia bot. hung. 40: 125-142.

PApp, B., Erzberger, P., Ódor, P., Hock, Zs., Szövényi, P., SZURdoki, E. and Tóth, Z. (2010): Updated checklist and red list of Hungarian bryophytes. - Studia bot. hung. 41: 31-59.

PAPp, B., ERzBerger, P. and MARKa, J. (2010): Contributions to the bryophyte flora of eastern Albania (Korça and Kolonja districts). - Studia bot. hung. 41: 61-88.

PAPP, B., ERZBERgER, P. and TSAKIRI, E. (2011): Contributions to the bryophyte flora of the Voras (Nidže) Mts (Greece and the former Yugoslav Republic of Macedonia). - Studia bot. hung. 42: 51-76.

PAPp, B. and Erzberger, P. (2011): Additions to the bryophyte flora of the Tara river canyon and the Durmitor area, Montenegro. - Studia bot. hung. 42: 31-39.

Marka, J., Papp, B., Erzberger, P., Colacino, C. and Sabovljević, M. (2012): Towards a red list of the Albanian bryophytes. - Studia bot. hung. 43: 13-25.

ERzberger, P. and Schröder, W. (2013): The genus Bryum (Bryaceae, Musci) in Hungary. Studia bot. hung. 44: 5-192.

Papp, B., Dragićević, S. and Erzberger, P. (2014): Contributions to the bryophyte flora of the Komovi Mts (Montenegro). - Studia bot. hung. 45: 17-31.

Németh, Cs. and Erzberger, P. (2015): Anacamptodon splachnoides (Amblystegiaceae): Hungarian populations of a moss species with a peculiar habitat. - Studia bot. hung. 46(1): 61-75.

Erzberger, P., Németh, Cs., Papp, B., Mesterházy, A., Csiky, J. and Baráth, K. (2015): Revision of the red list status of Hungarian bryophytes 1 . New occurrences of species previously thought to be regionally extinct or without recent data. - Studia bot. hung. 46(2): $15-53$.

Erzberger, P. (2016): The genus Fissidens (Fissidentaceae, Bryophyta) in Hungary. - Studia bot. bung. 47(1): 41-139.

Papp, B., Alegro, A., Erzberger, P., Szurdoki, E., Šegota, V. and Sabovljević, M. (2016): Bryophytes of saline areas in the Pannonian region of Serbia and Croatia. - Studia bot. hung. 47(1): 141-150.

Baráth, K., Erzberger, P., Kovács, A. and Papp, B. (2016): Heterocladium dimorphum (Heterocladiaceae, Bryophyta) - an old element of the Hungarian bryophyte flora rediscovered. - Studia bot. hung. 47(2): 269-278. 
His colleagues greet Peter Erzberger to his 70th birthday with the following selection of photos from their common life

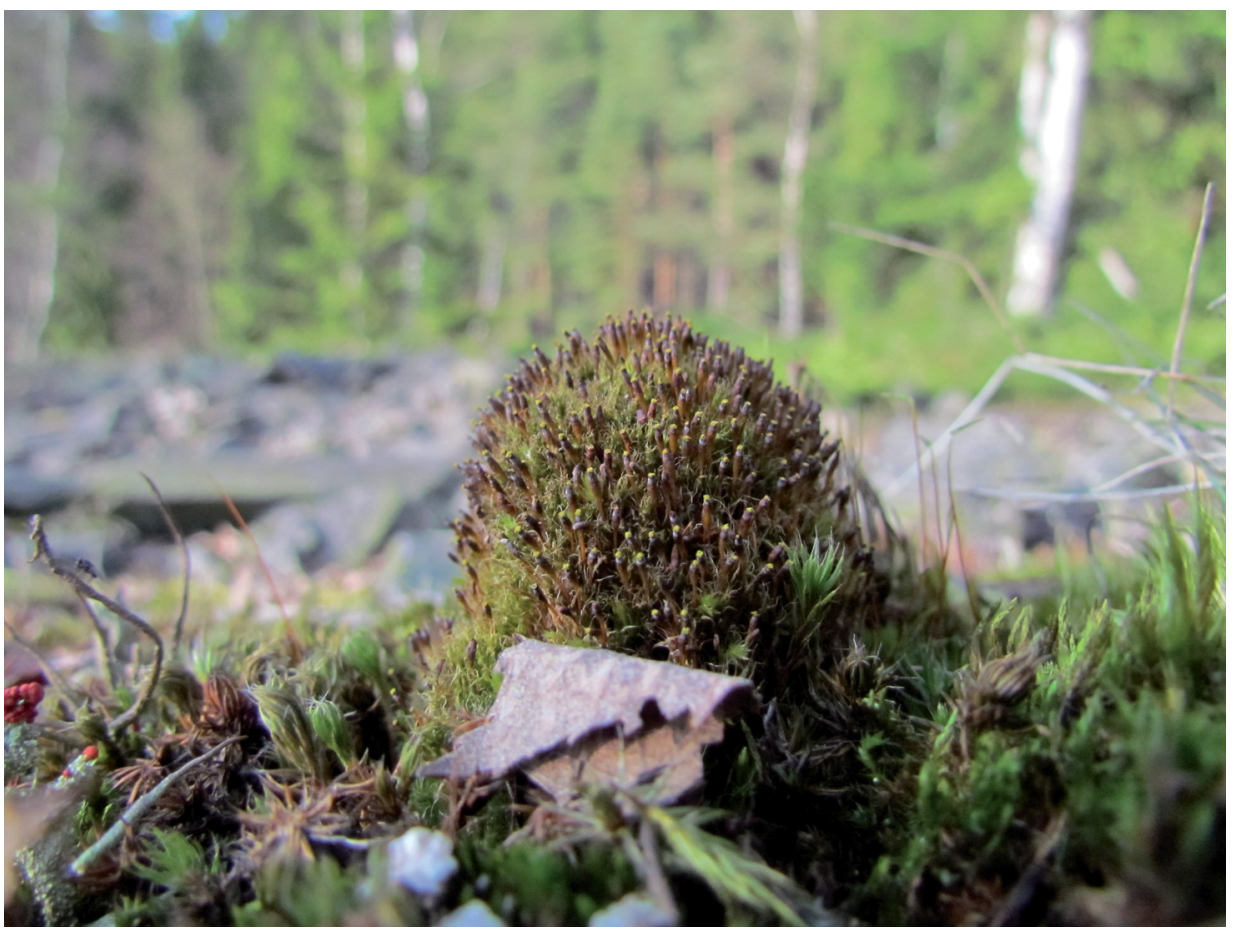

With this picture of Tetraplodon angustatum, taken at the Rehbachhalde near Lehesten, we cordially congratulate Peter Erzberger to his 70th birthday on April 29. We wish all the best to him for continuing his successful moss field mapping in Hungary. We also would like to thank him again for his participation in preparing the "Verbreitungsatlas der Moose Deutschlands", which was published in 2007 in three volumes. Our cooperation started more than 25 years ago with data from the district of Siegen-Wittgenstein, and from Berlin and Brandenburg, where we met him on excursions quite often. His articles on Hedwiga stellata in Germany are particularly appreciated.

Ludwig Meinunger and Wiebke Schröder 


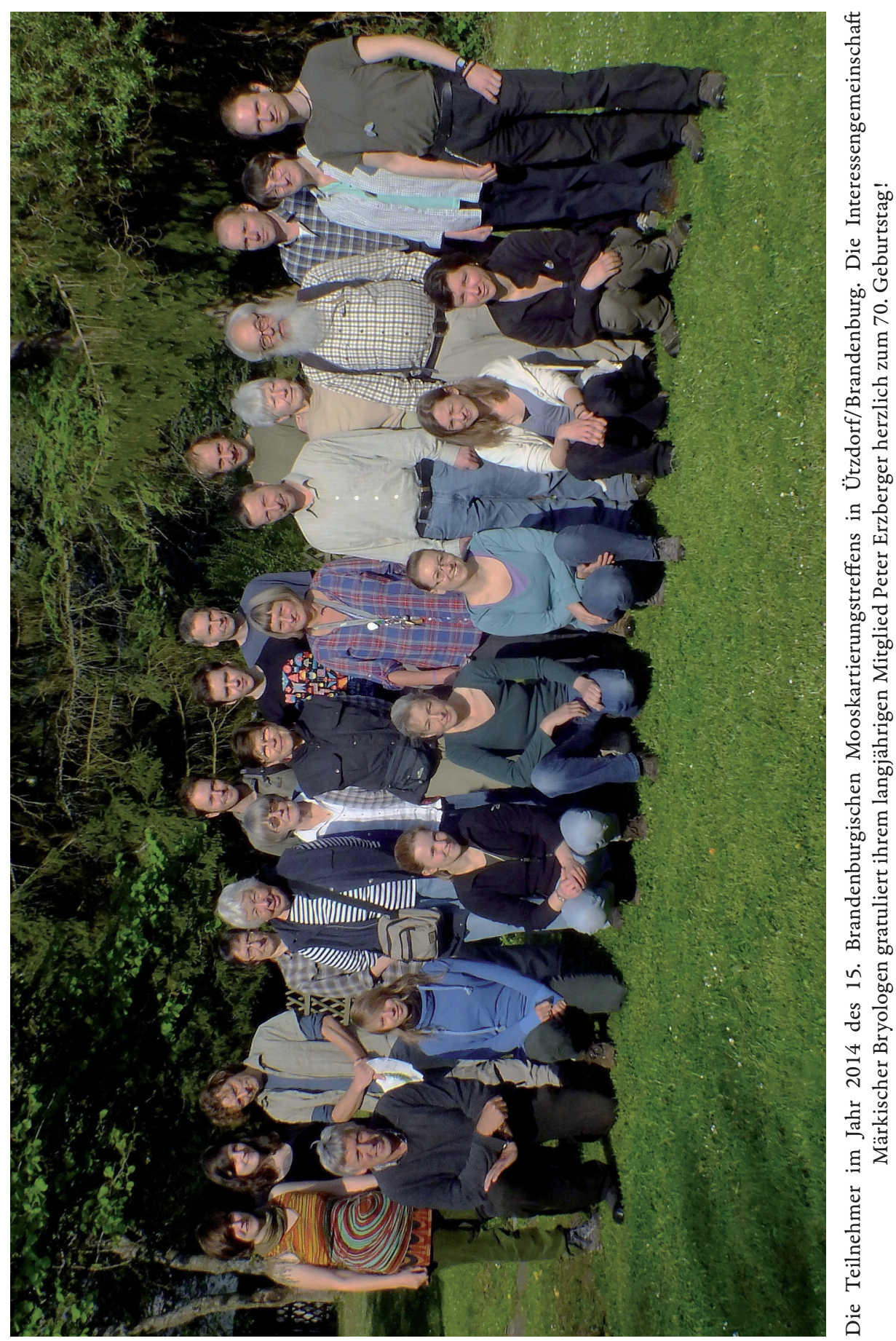




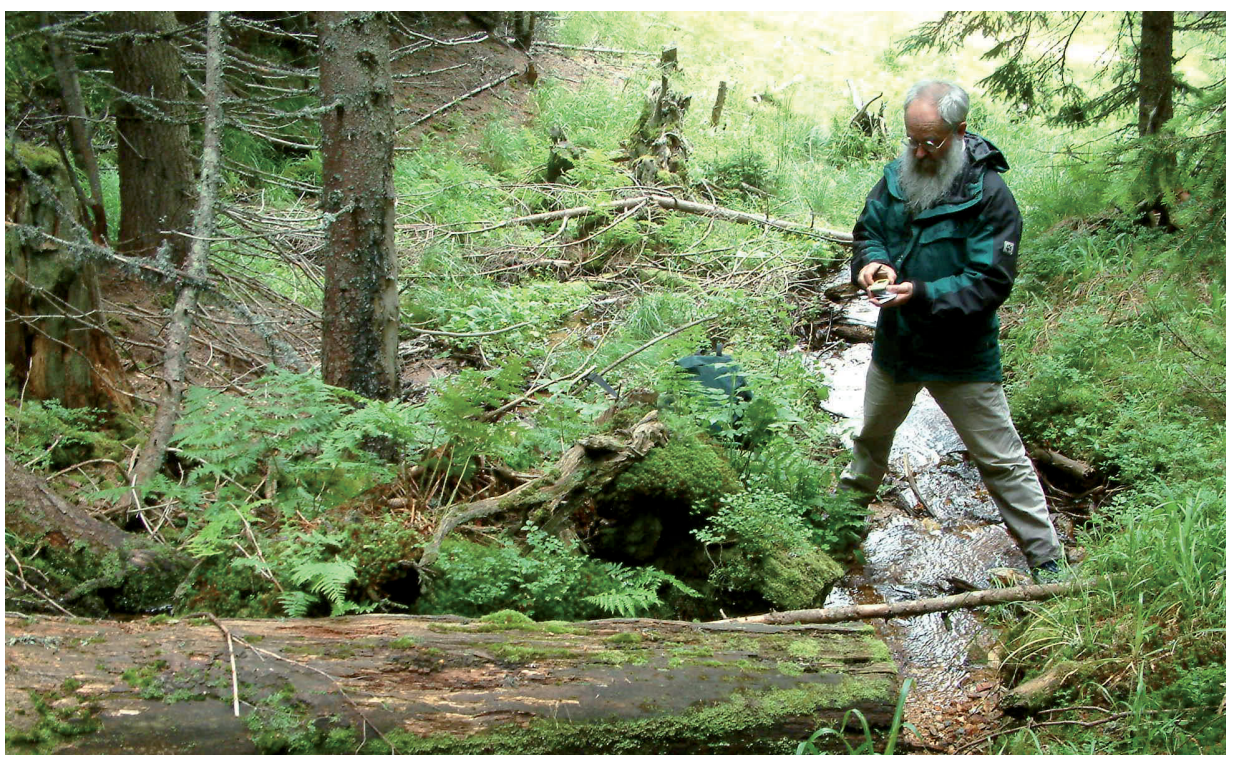

Golija-Studenica Biosphere Reserve (Serbia), July 2003; Peter Erzberger is collecting bryophytes along a stream in Odvraćenica. (Photo: Beáta Papp)

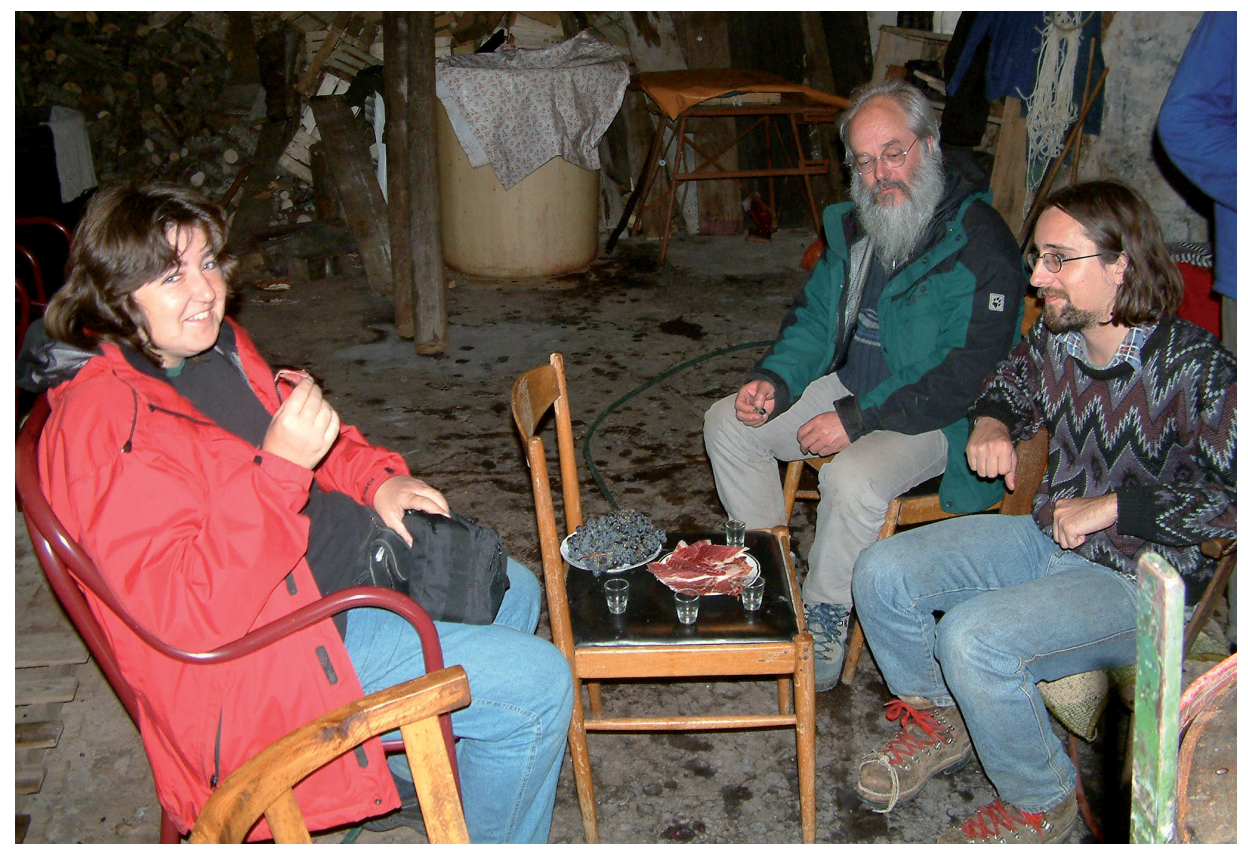

Lovćen Mts (Montenegro), October 2003; evening party in Njeguši village with traditional Njeguš bacon and rakija; Beáta Papp, Peter Erzberger and Dániel Pifkó. (Photo: Zoltán Barina) 


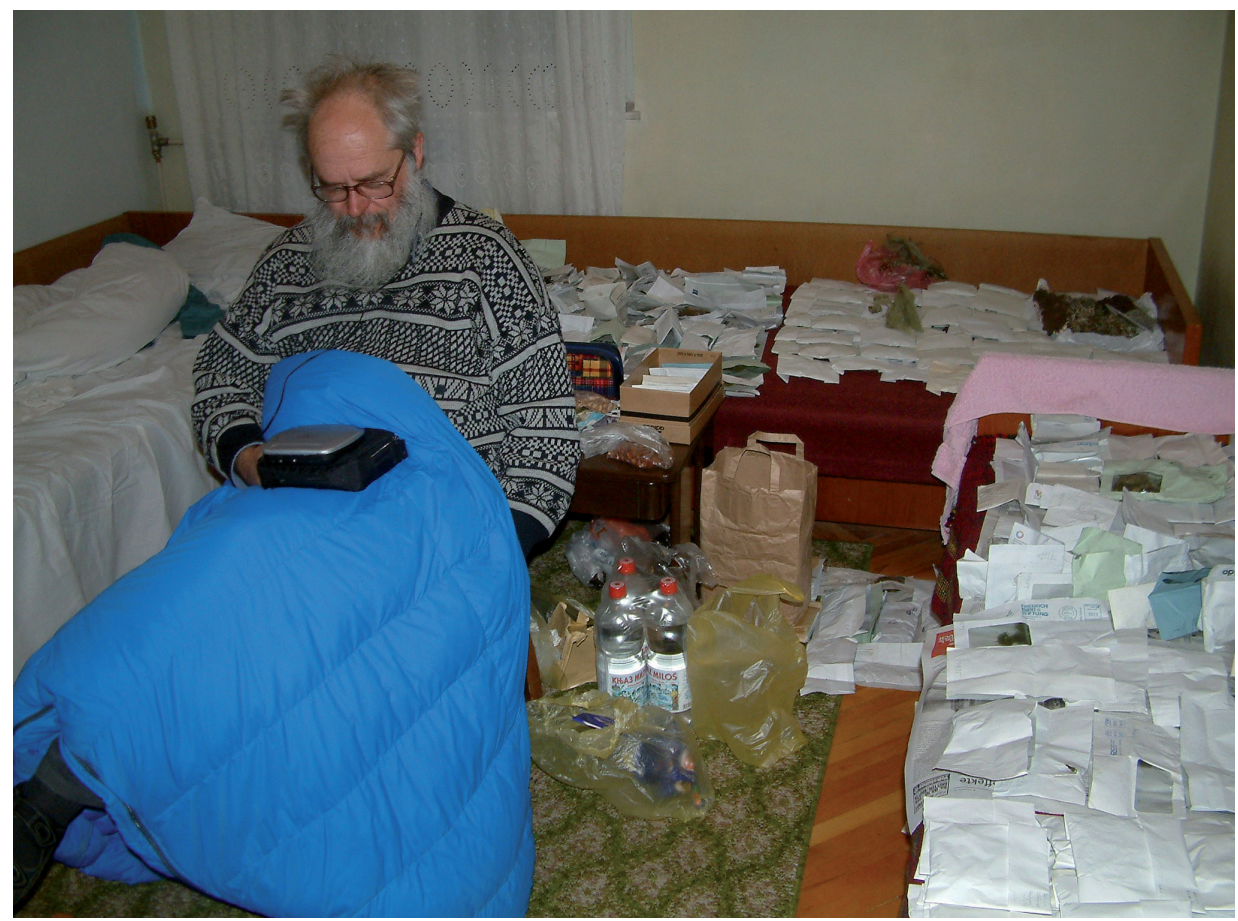

Durmitor Mts (Montenegro), October 2004; Peter Erzberger is listening to music as a relaxation among desiccating bryophyte specimens in the room in Žabljak. (Photo: Beáta Papp)

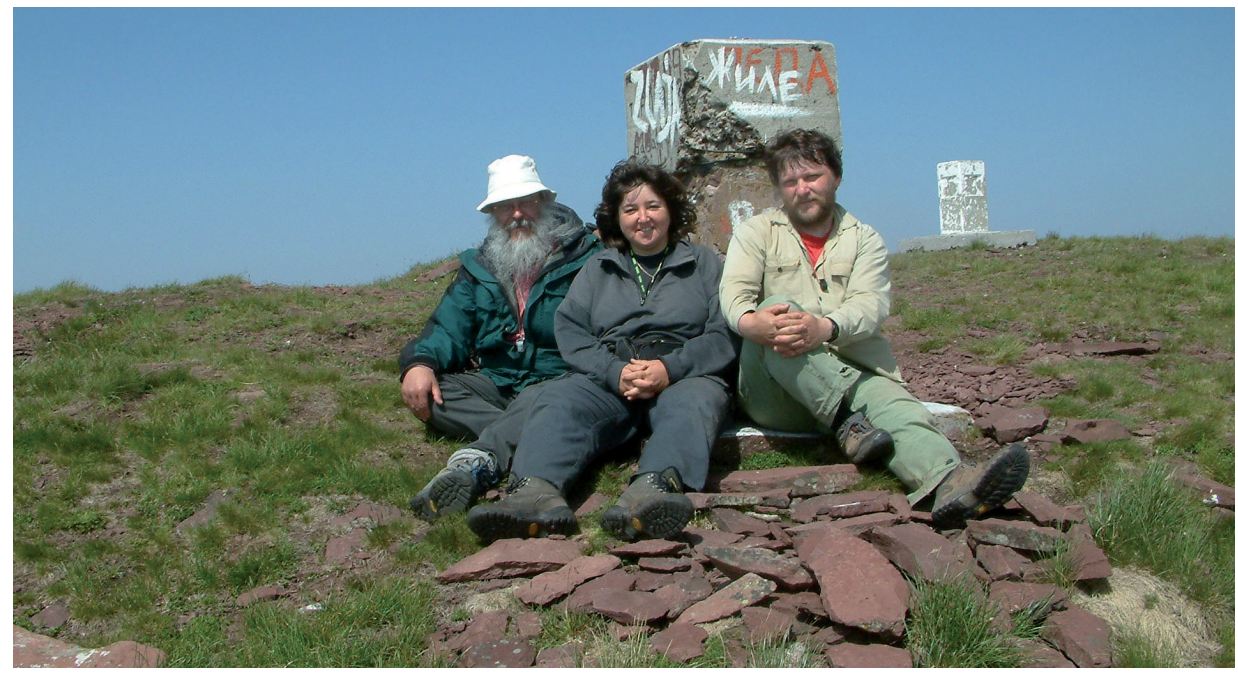

Stara Planina Mts (Serbia), June 2005; Peter Erzberger, Beáta Papp and László Lőkös in the Midžor peak at the border of Serbia and Bulgaria. (Photo: Beáta Papp, self-timer) 


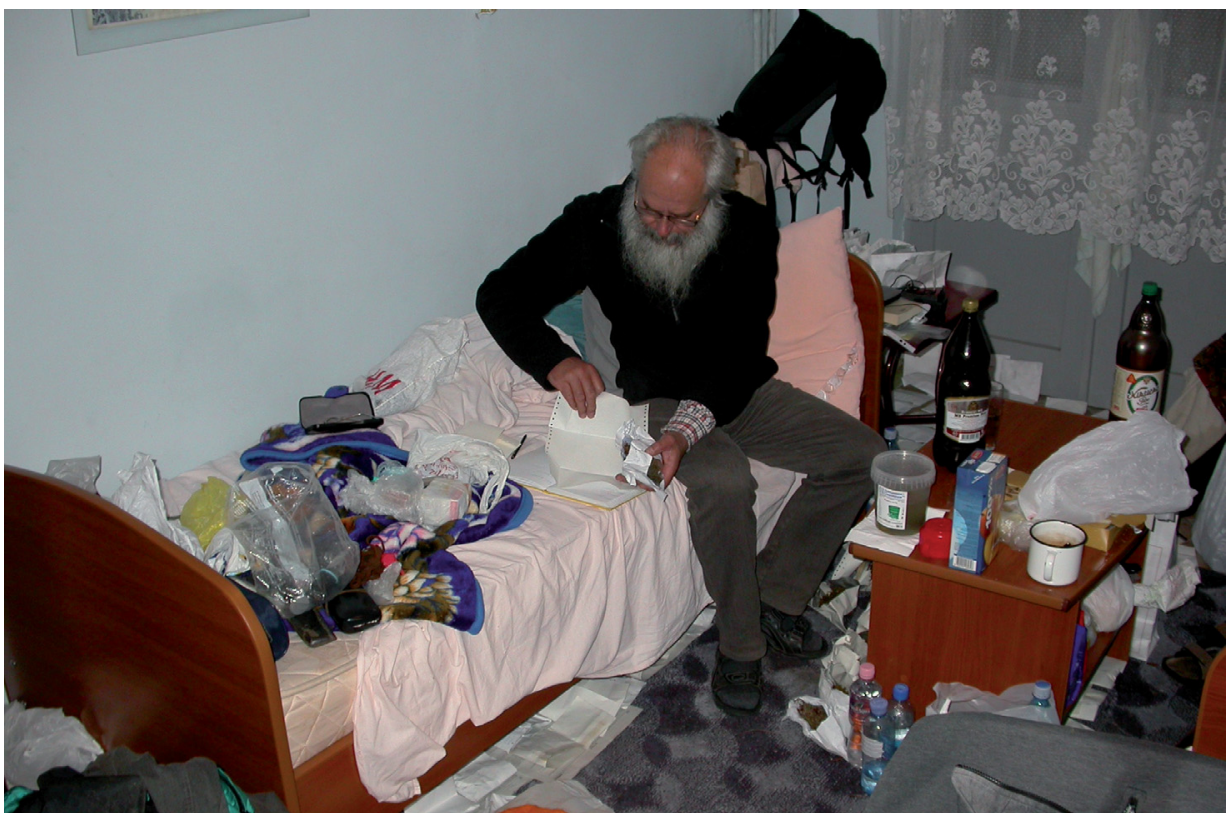

Prokletije Mts (Montenegro), September 2006; Peter Erzberger in the room of Santea Bar in Gusinje. (Photo: Beáta Papp)

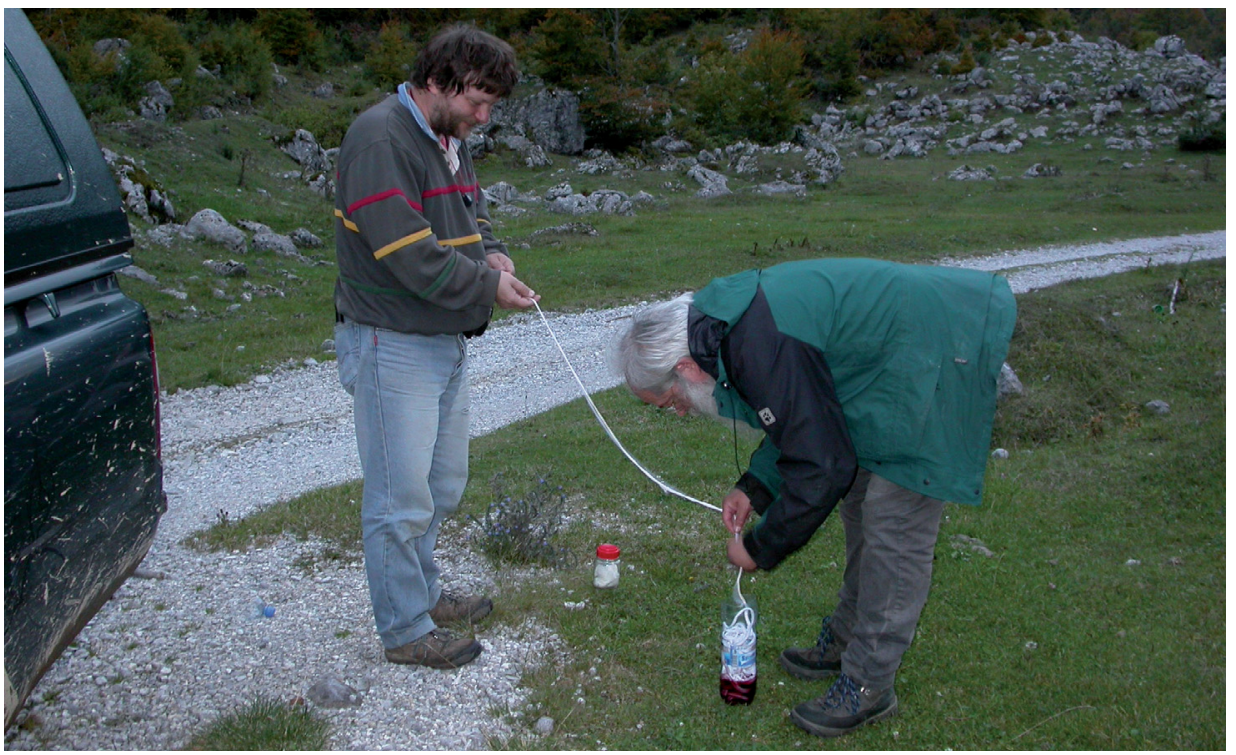

Prokletije Mts (Montenegro), September 2006; Collecting butterflies for the Zoological Department of HNHM, Peter Erzberger and László Lőkös are preparing for evening butterfly trapping with a string soaked with red wine. (Photo: Beáta Papp) 


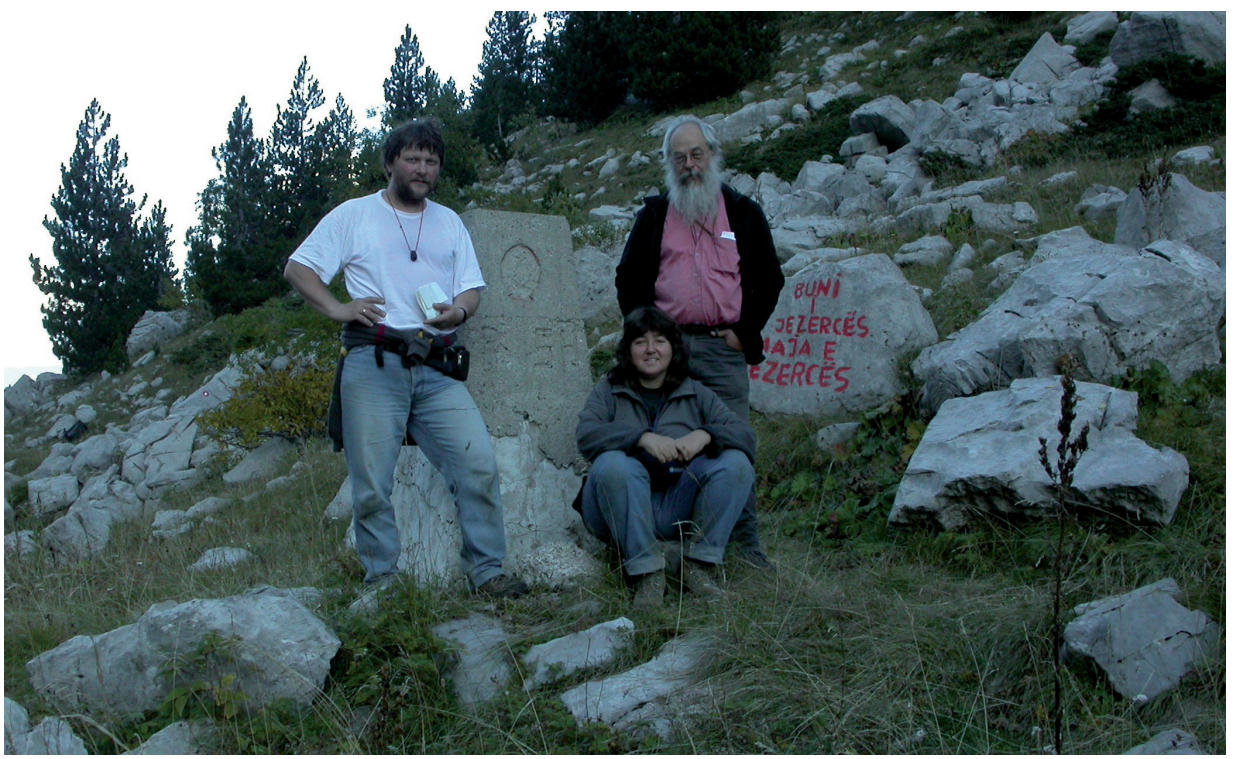

Prokletije Mts (Montenegro), first (illegal) visit in Albania, September 2006; László Lőkös, Beáta Papp, Peter Erzberger at the Albanian border stone. (Photo: Beáta Papp)

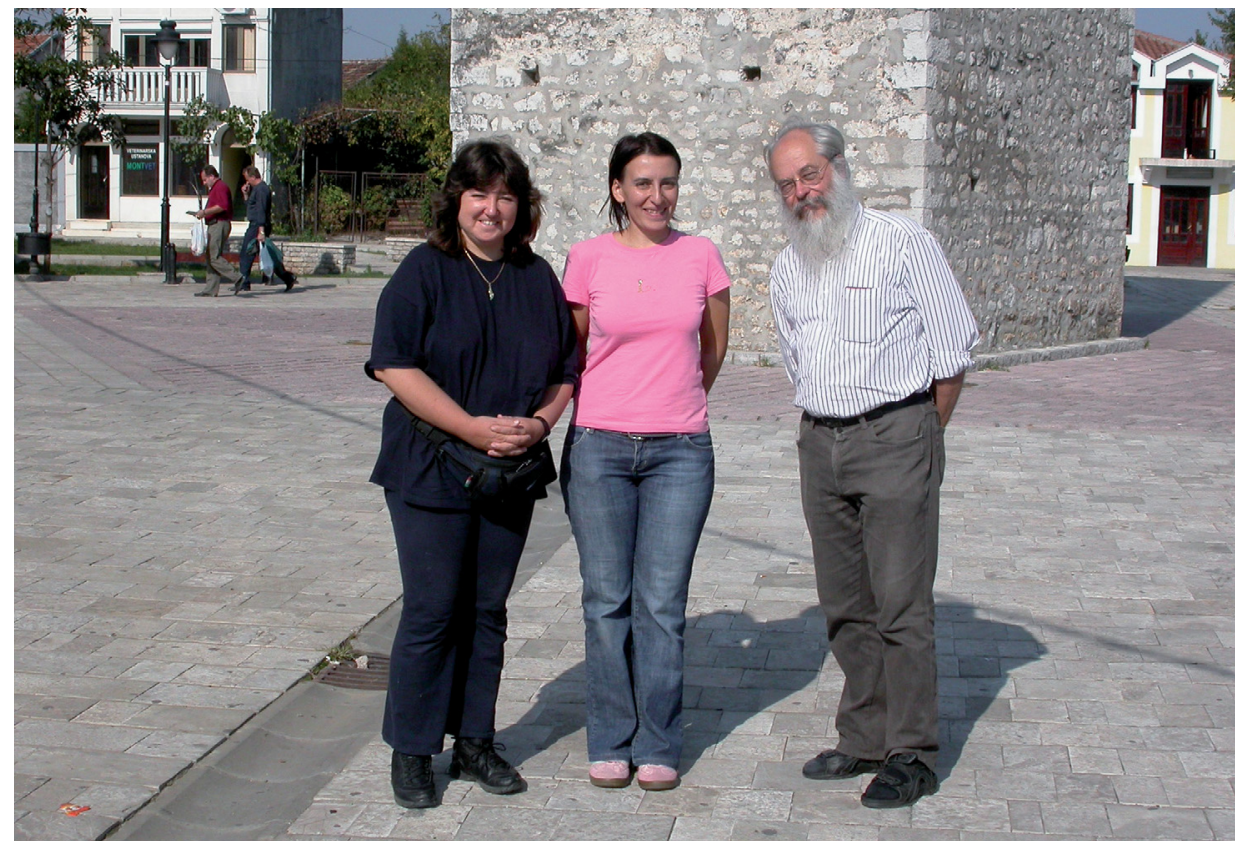

Prokletije Mts (Montenegro), September 2006; Beáta Papp, Snežana Dragićević and Peter Erzberger in front of the Natural History Museum of Montenegro in Podgorica. (Photo: László Lőkös) 


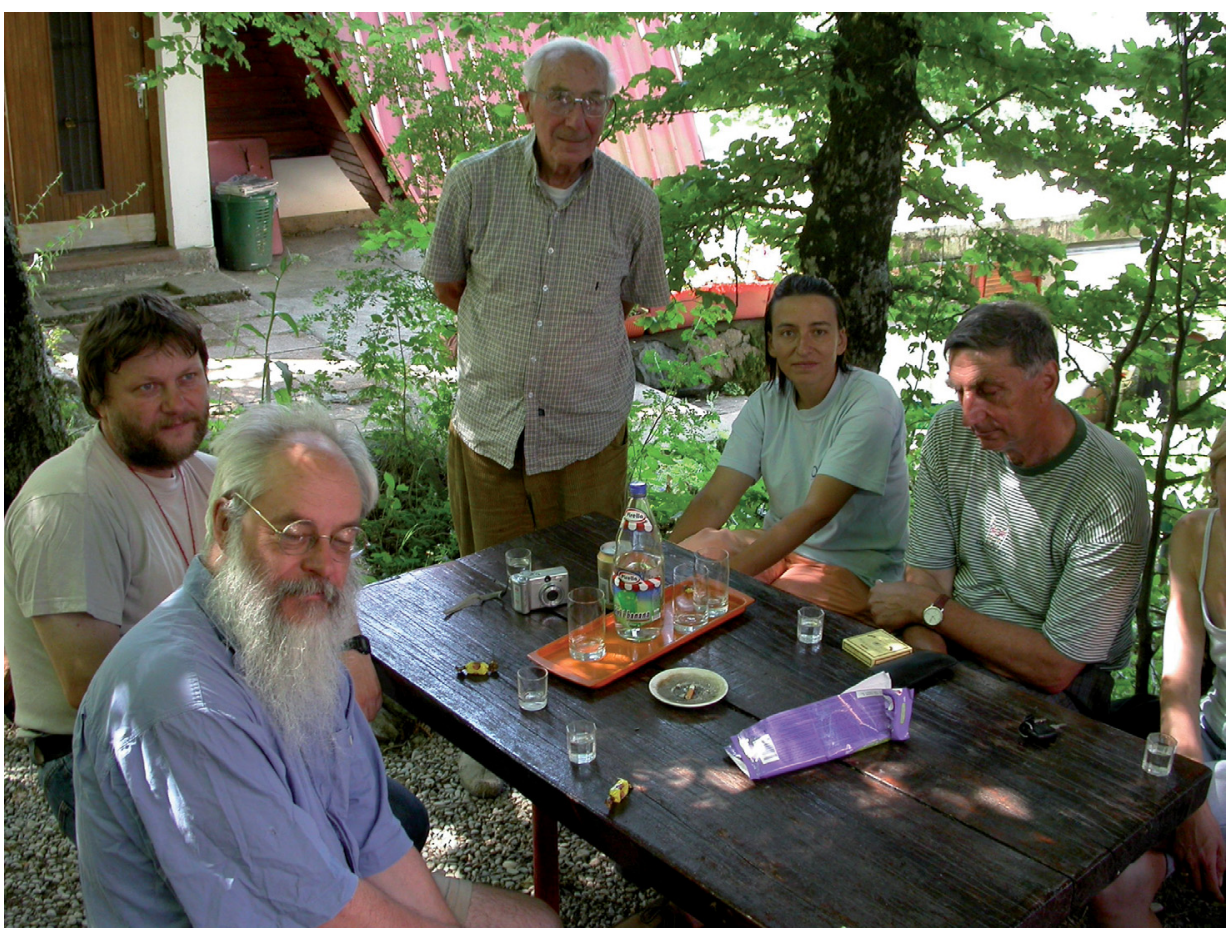

Kolašin town at Bjelasica Mts (Montenegro), June 2007; Rakija party in the house of Daniel Vincek in the Alpine Botanical Garden of Montenegro; László Lőkös, Peter Erzberger, Daniel Vincek, Snežana Dragićević and a Montenegrin mountain climber. (Photo: Beáta Papp)

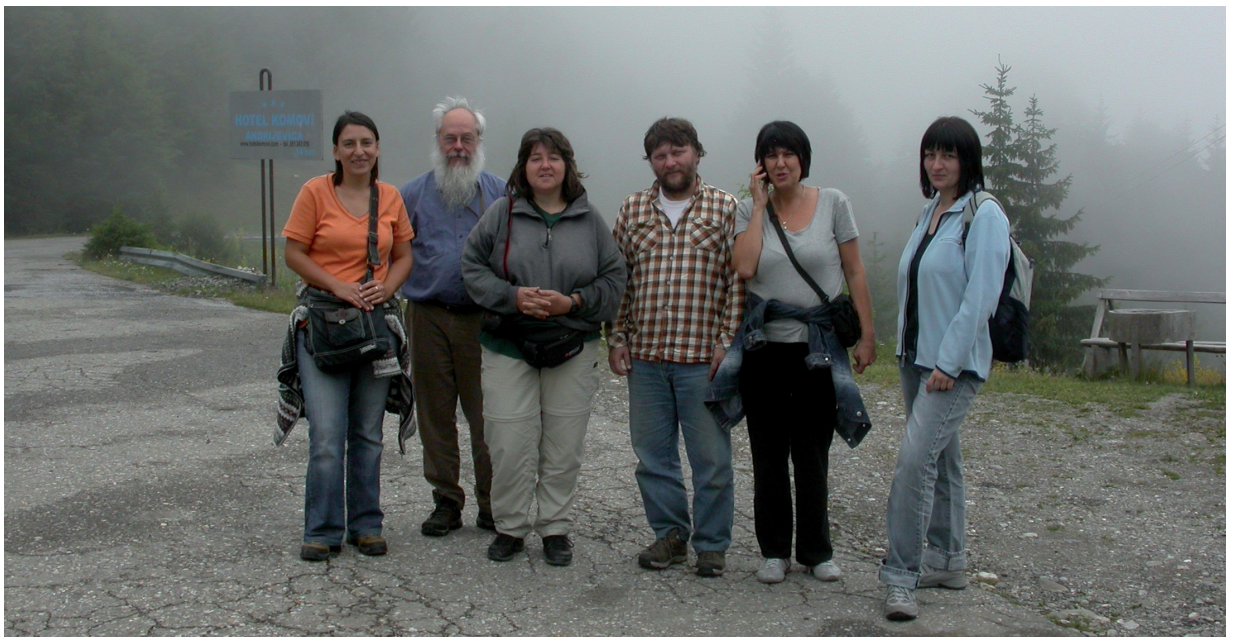

Komovi Mts (Montenegro), July 2008; Snežana Dragićević, Peter Erzberger, Beáta Papp, László Lőkös and colleagues from the Natural History Museum of Montenegro. (Photo: Beáta Papp, self-timer) 


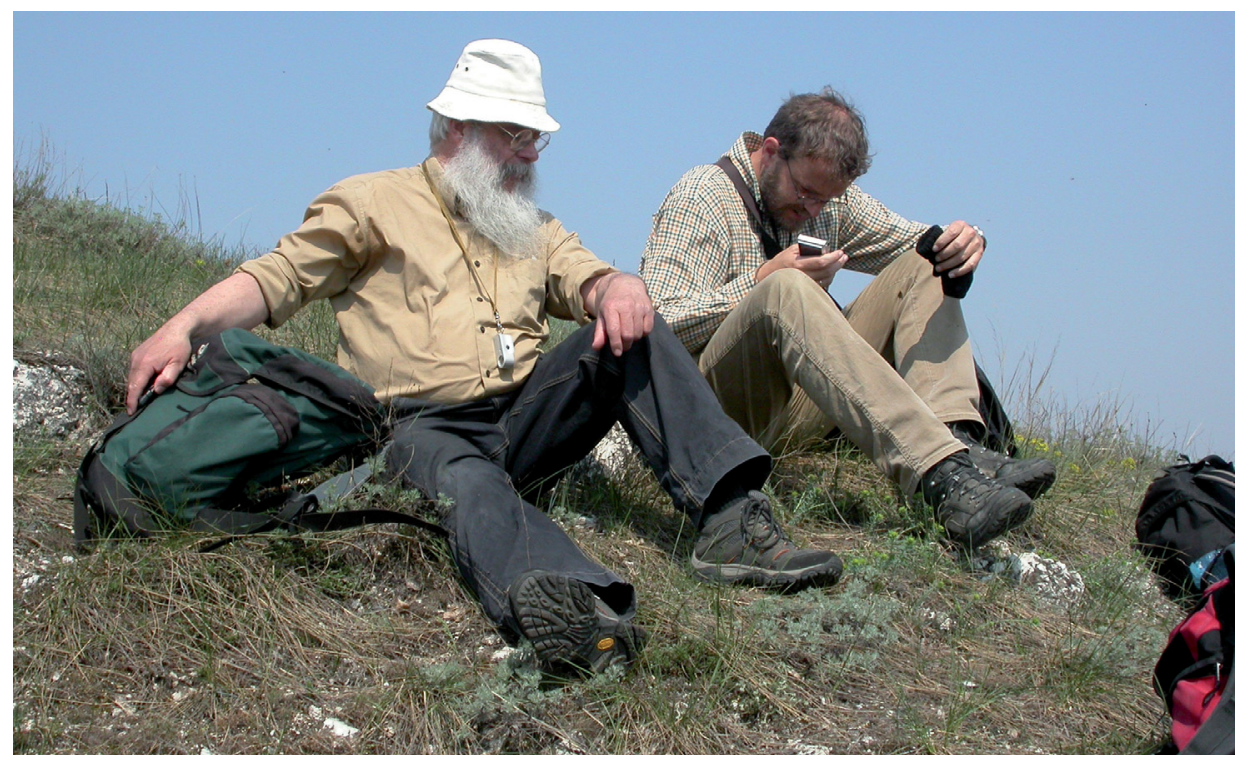

Vértes Mts (Hungary), April 2009; Peter Erzberger and Christian Berg (Graz) on a dolomite grassland in Kölik Hill. (Photo: Beáta Papp)

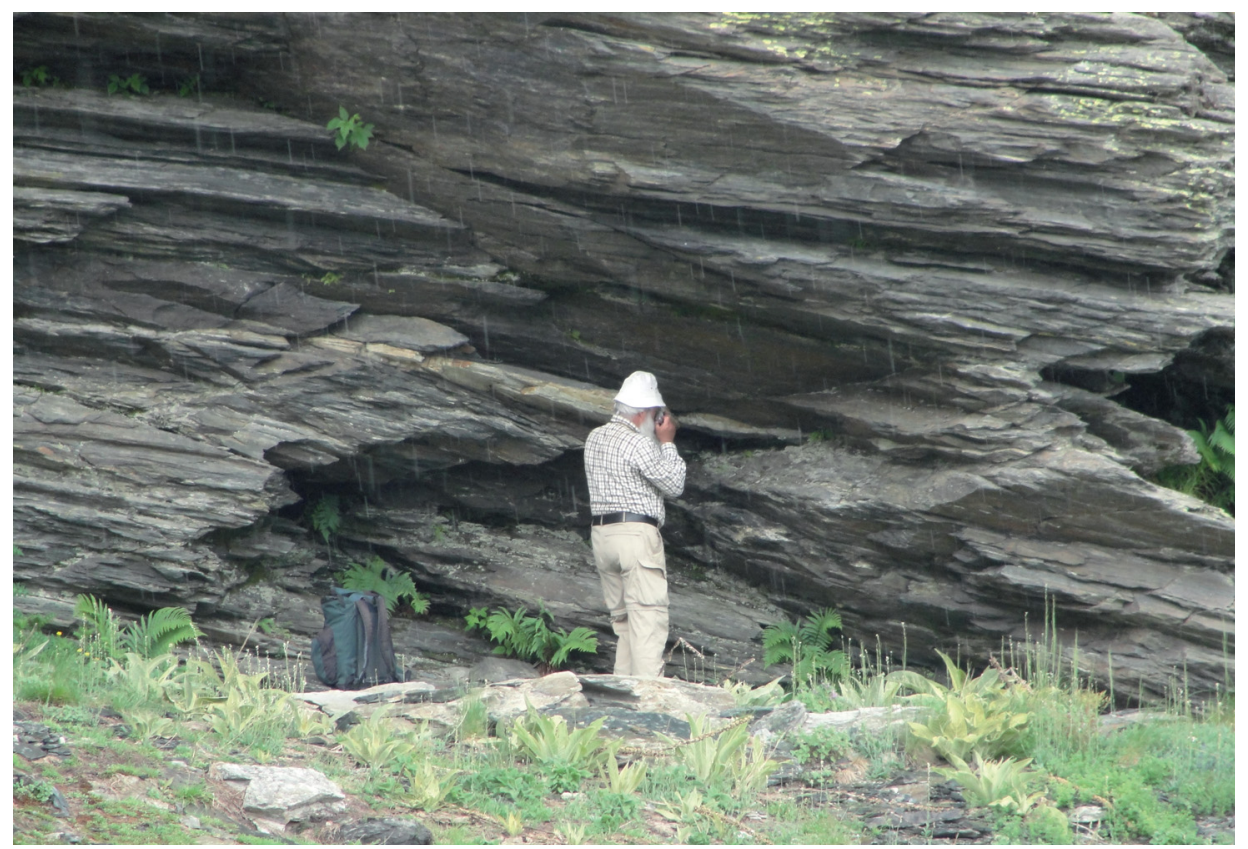

Pelister Nationa Park, shelter place at ca $2000 \mathrm{~m}$ a.s.l. along the path to lake Golemo Ezero (Republic of Macedonia), 21 July 2010; Peter Erzberger. (Photo: László Lőkös) 


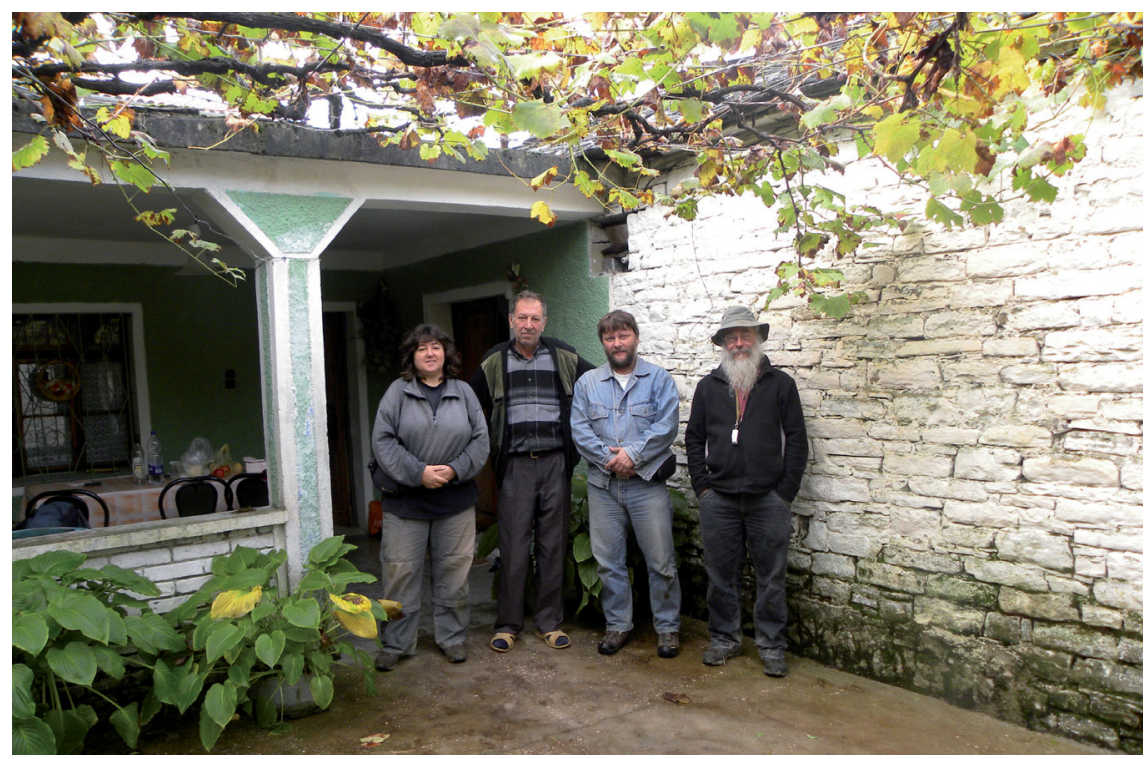

Dhëmbeli Mts (Albania), October 2010; in the house of Jani Marka's family in Hoshtevë village; Beáta Papp, father of Jani Marka, László Lőkös and Peter Erzberger. (Photo: Jani Marka)

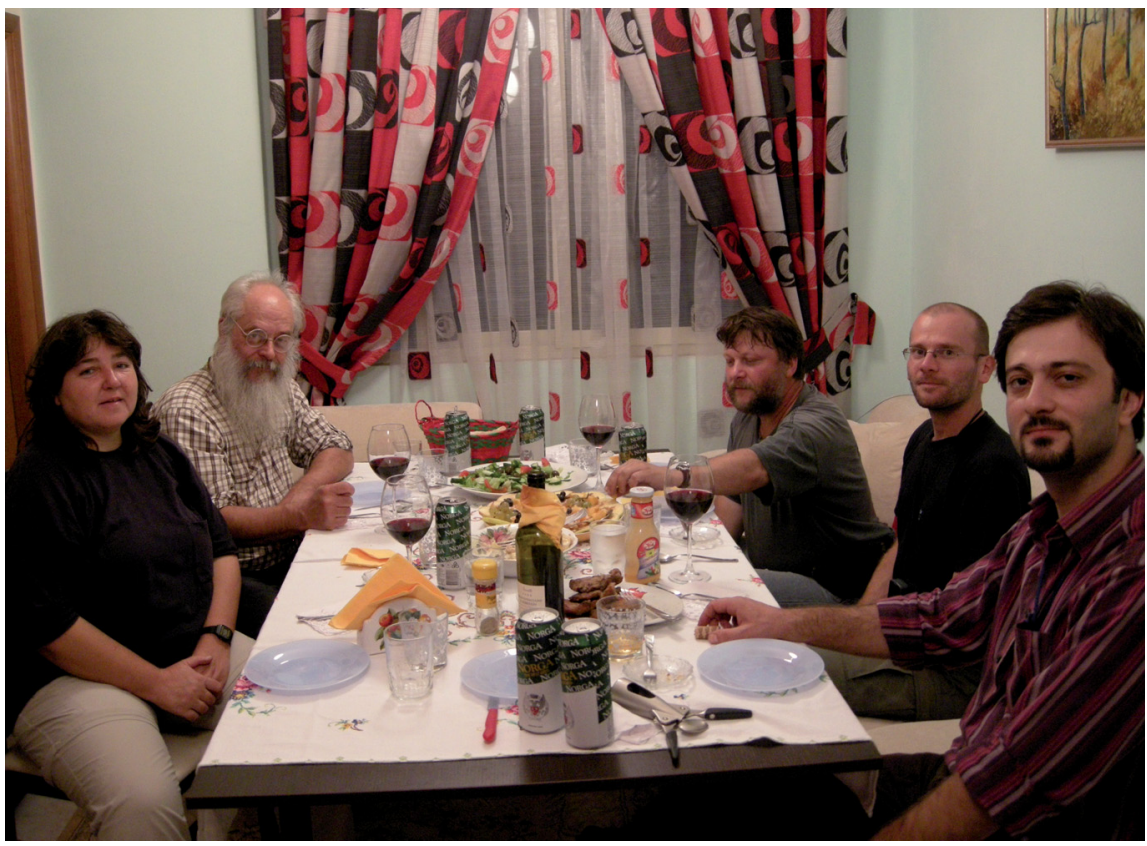

Tirana (Albania), October 2010; dinner party at the family of Jani Marka, from left to right: Beáta Papp, Peter Erzberger, László Lőkös, Zoltán Barina, Jani Marka. (Photo: Zoltán Barina, self-timer) 


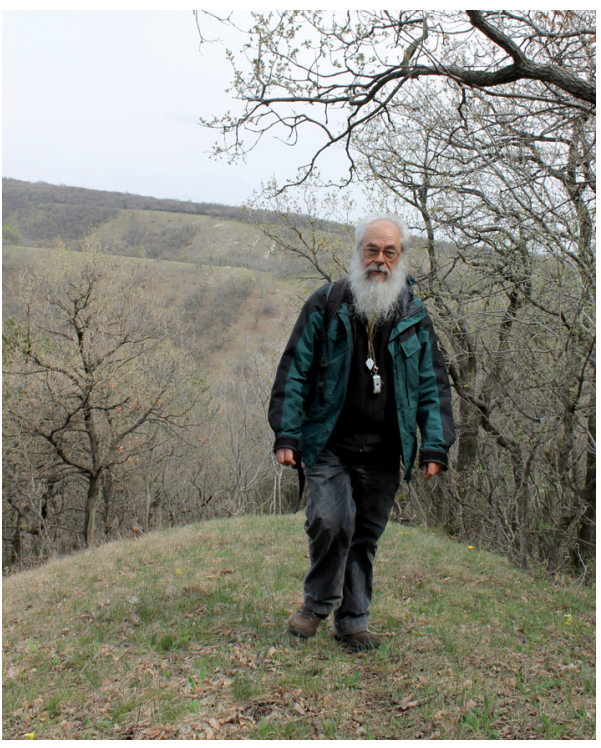

Vértes Mts, Csákberény (Hungary), 13.04.2012. (Photo: Csaba Németh)

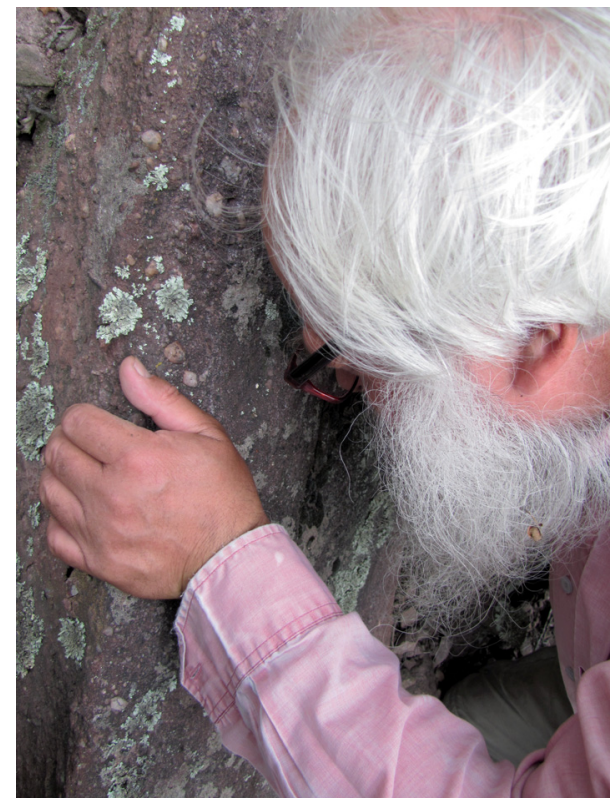

Mecsek Mts, Jakab-hegy (Hungary), 08.10.2014; Mimicry, studying Grimmia montana growing on red sandstone substrate. (Photo: János Csiky)

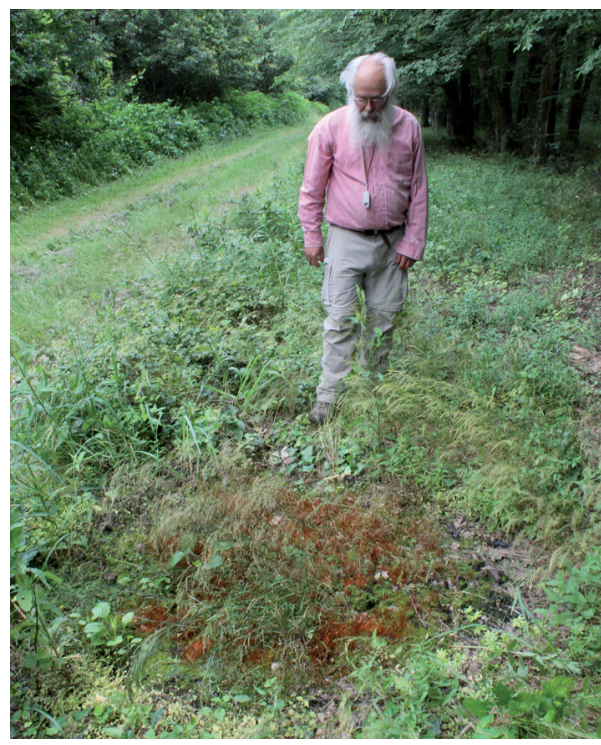

Keszthely Mts (Hungary), 28.06.2013, fireplace with Peter Erzberger and Funaria hygrometrica.

(Photo: Csaba Németh)

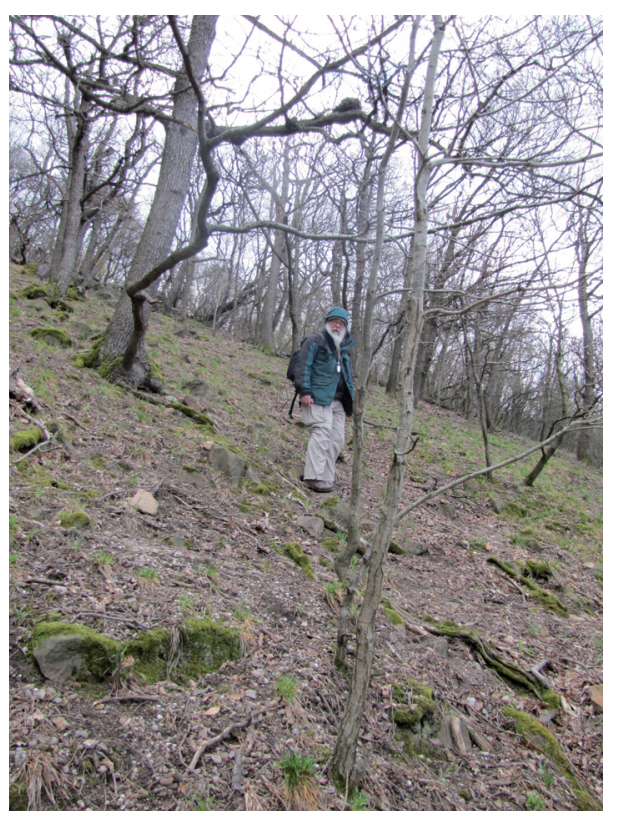

Buda Mts, Hűvösvölgy (Hungary), 03.04.2015, when finding Buxbaumia aphylla.

(Photo: János Csiky) 


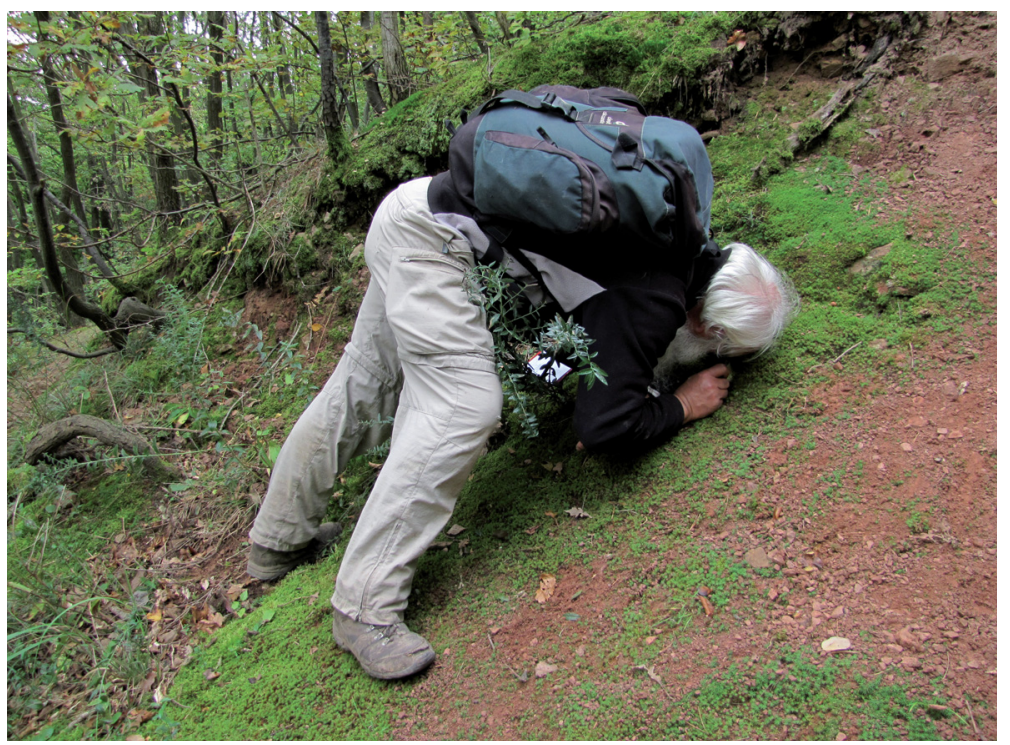

Mecsek Mts, Éger-völgy (Hungary), 08.10.2014; when finding Gymnocolea inflata. (Photo: János Csiky)

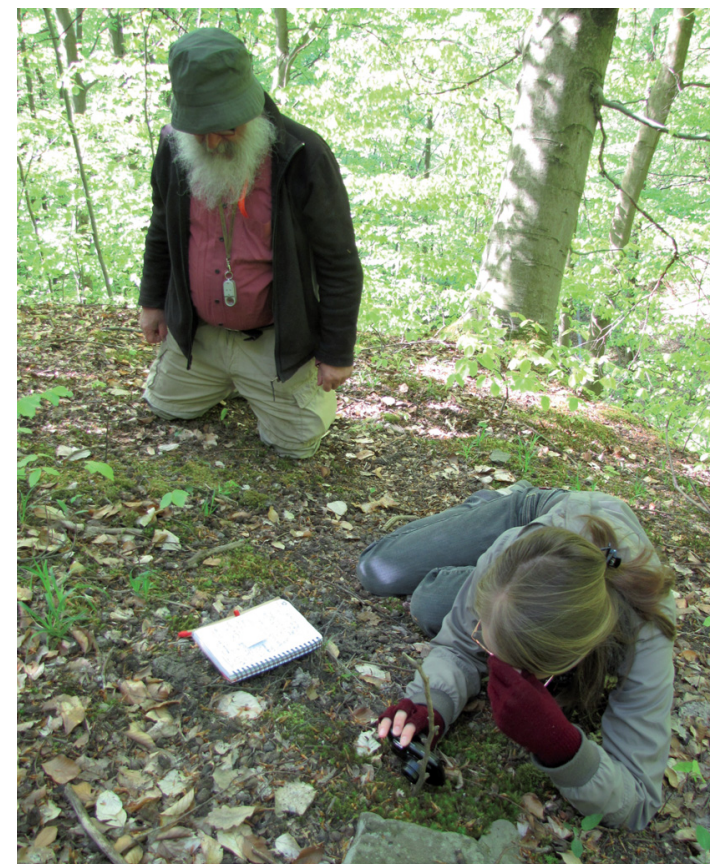

Medves Mts, Gortva-völgy (Hungary), 15.04.2016; survey of Buxbaumia aphylla with Judit Deme. (Photo: János Csiky) 


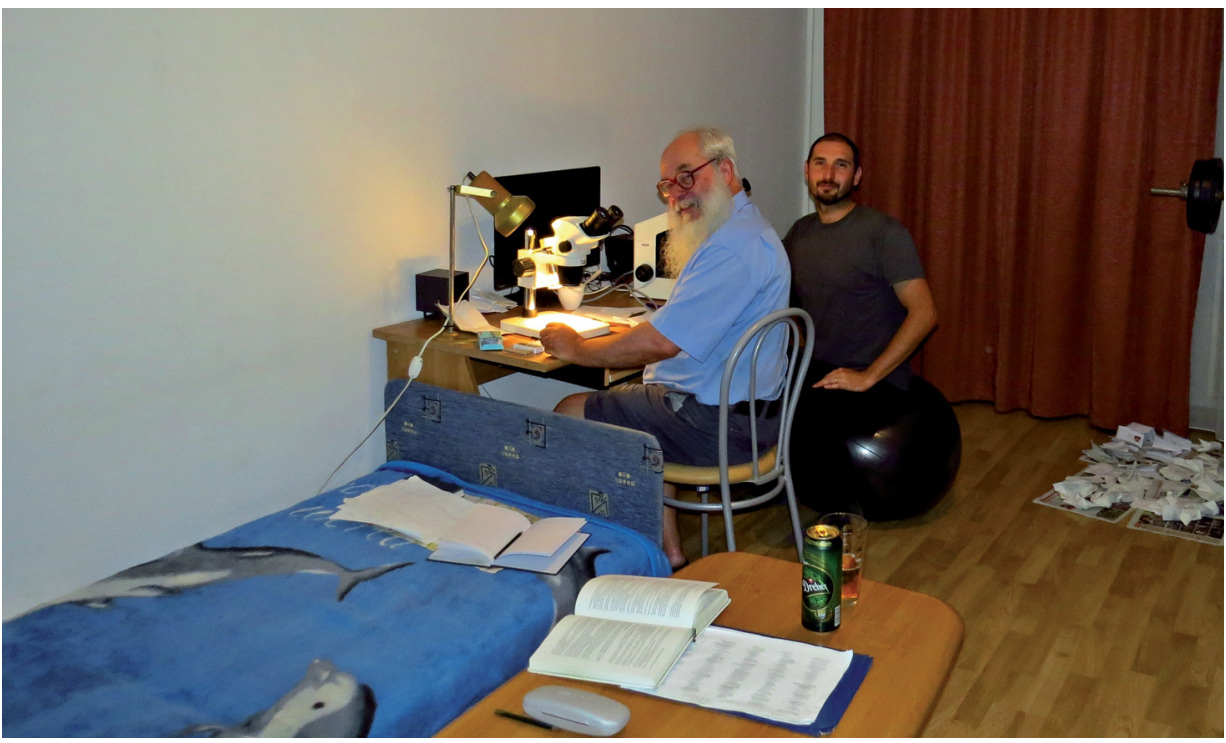

Szombathely (Hungary), 05.07.2016; Peter and Kornél Baráth try to identify some interesting moss species collected in the Kőszeg Mts. (Photo: Dr Baráthné Kocsis Szilvia)

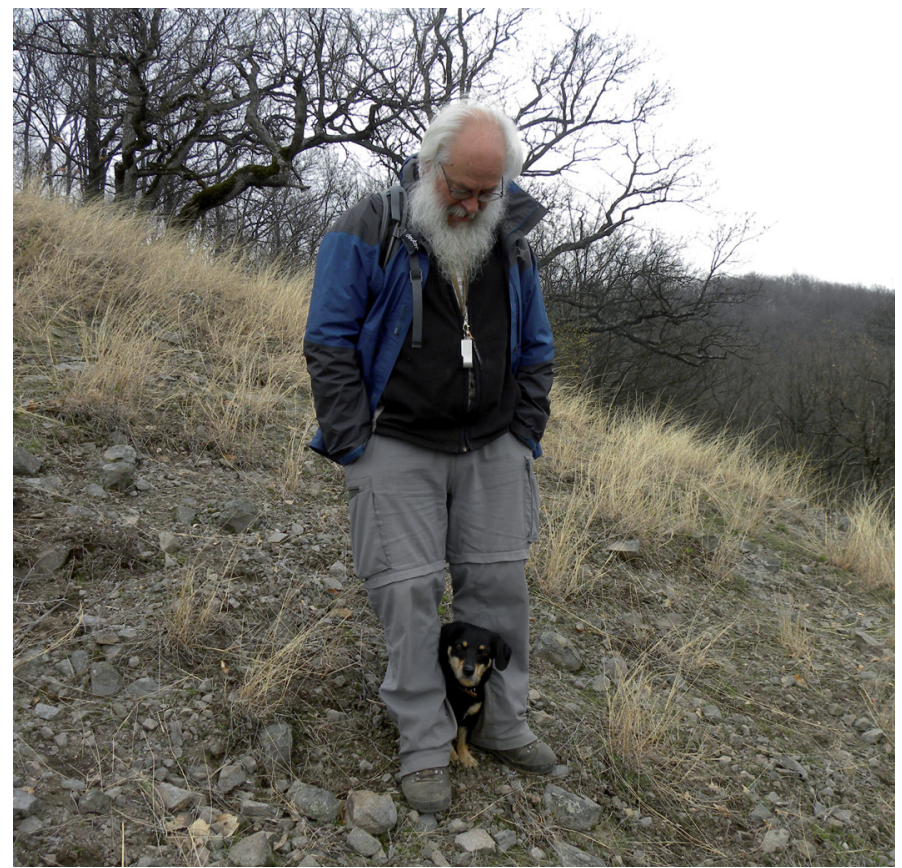

Visegrád Mts, in a grassland above Lepence (Hungary), March 2017; Peter Erzberger with Rozi (dog of Beáta Papp). (Photo: Beáta Papp) 


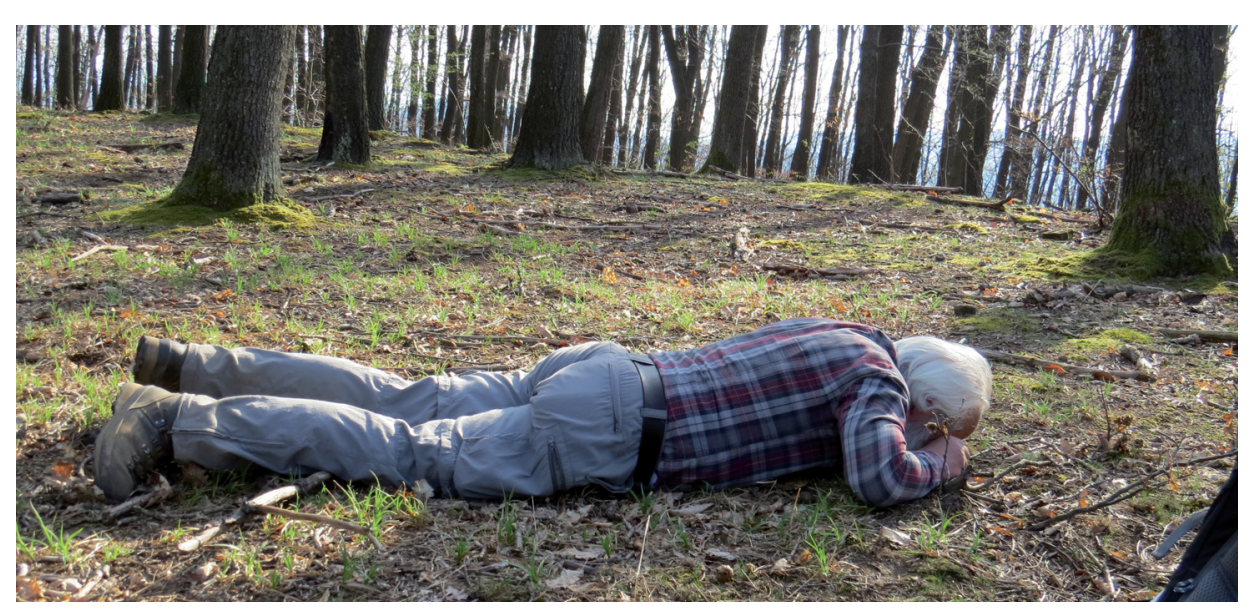

Mátra Mts (Hungary), 30.03.2017; Peter is investigating some individuals of Buxbaumia viridis. (Photo: Kornél Baráth)

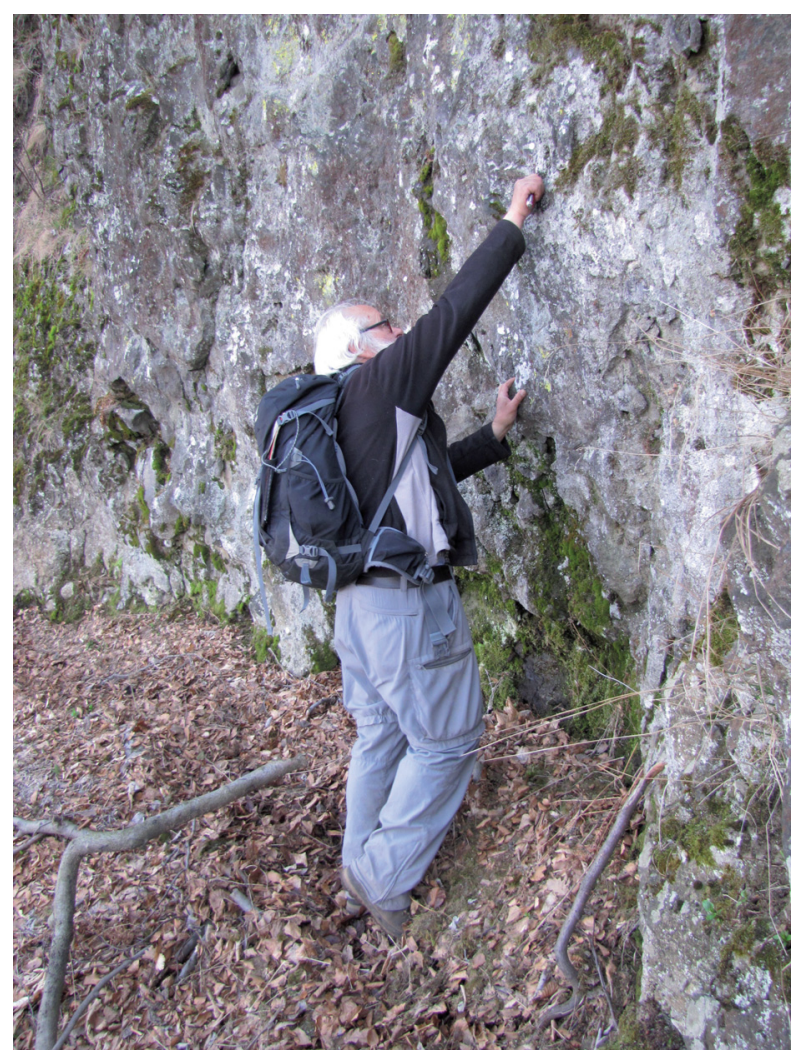

Mátra Mts, Saskő (Hungary), 31.03.2017; when finding Seligeria recurvata. (Photo: János Csiky) 